\title{
Determinants of Financial Sustainability for Non-Governmental Organizations in Nakuru County, Kenya
}

\author{
Silvanus Muthoka Mutinda ${ }^{1}$, Solomon $\mathrm{Ngahu}^{2}$ \\ ${ }^{1,2}$ JKUAT, Department of Business Administration
}

\begin{abstract}
The financial sustainability of an organization is a measure of the organization's ability to meet its financial obligations. This study sought to establish the determinants of financial sustainability of NGOs in Nakuru County, Kenya. The study targeted 168 program managers, grants managers and accountants in 56 registered NGOs operating in Nakuru County. A sample size of 96 respondents was selected through stratified random sampling. Data was collected using questionnaires and analyzed using descriptive statistics (means and standard deviations) and inferential statistics (Pearson correlation and multiple regression analysis) with the aid of the statistical package for social sciences (SPSS) version 24. The study established that financial resources mobilization capacity did not significantly influence the financial sustainability in NGOs. However, internal financial control systems were found to have a positive significant influence on financial sustainability of the NGOs in Nakuru County. It is recommended that the management of NGOs should strengthen internal financial control systems in order to facilitate transparency in the management of NGOs.
\end{abstract}

Keywords: NGOs, Nakuru County, Financial sustainability, Internal Control Systems, Resource Mobilization Capacity, Sustainability

\section{Introduction}

Financial sustainability is an important factor in the long-term survival and effectiveness of NGOs. According to Lynn (2013) the more there are different sources of funds available the more financially sustainable an NGO is. In other words, financial sustainability of an NGO depends on its ability to diversify its sources of funds. In practice NGOs that are not dependent on a particular funding stream is likely to remain sustainable. A sustainable NGO is one that can continue to fulfill its mission over time and meet the needs of its key stakeholders, particularly its beneficiaries and supporters (Malvern, 2002). Sustainable NGOs are those that are able to respond strategically and effectively to such external changes, revise their mission and objectives accordingly, access new sources of income, and adapt their systems and processes to meet the new challenges.

According to Ashoka and Mango (2015) NGOs need to invest in building relationships, risk management and basic good financial practice in order to remain sustainable. Apart from being able to raise money from a variety of sources, financially sustainable NGOs actively invest in developing and maintaining strong personal relationships with their key stakeholders particularly their donors, supporters, volunteers, staff and beneficiaries (Pratt \& Hailey, 2012). They also have sufficient internal capacity to assess and manage the risks associated with funding and financial resources on a regular basis and in a way that both board members and managers can understand and engage with. Sustainable NGOs also have built sufficient financial reserves, as well as strategically manage and finance all organizational costs and overheads (Pratt \& Hailey, 2012). Moreover, effective financial management and effective fund raising are essential ingredients of NGO's sustainability. According to Serageldin (2006) sustainability is determined by several financial and human capital related factors. An NGO is considered sustainable if it has diverse funding sources, so that if one or two left the scene, no great harm would be done to the organization's capacity to continue its work (Pratt \& Hailey, 2012). This is more applicable in the United States, where a great variety of fundraising options are available to an NGO (Brinkerhoff and Goldsmith, 2010). In South America and Latin America, NGOs have not fully realized their motive for formation. In Papua New Guinea the management of NGOs have been influenced by external forces such as local ownership, local accountability, control and membership. In Middle East and Asian countries, NGOs have been affected by environmental threats such as insecurity (Stoner, 2003). In African countries the NGOs' poor sustainability is the result of poorly prioritizing of projects which often relate to strategic errors made during the formation of the NGOs (Roll, 2009).

Although traditional nonprofit organizations regard fundraising and charitable donations as their primary source of revenue, they also rely on grants, contracts for service, and sales of goods and services to finance operations and capital improvements (Carroll \& Stater (2009). Tuckman and Chang (2009) opine that even within a resource rich environment, the financial stability of nonprofit organizations depends upon effective financial management practices that reduce the volatility of the revenue portfolio and have the potential to increase the organization's equity. Clark (2003) advocates for adoption of a strategy of 
diversification that leads to greater stability in the revenue structure which potentially makes sustainability more likely.

In Kenya, NGOs are experiencing a myriad of problems that include ineffective boards, absence of strategic planning activities, poor recording practices, lack of necessary policies and procedures, high turnover of employees and volunteers and dependence on a limited number of funding sources (Padilla, Staplefoote \& Morganti, 2012). Effective financial management practices are therefore essential in improving financial sustainability of the NGOs. However, a number of financial factors such as financial resource mobilization capacity and internal financial control systems may influence the sustainability of NGOs in Kenya (Besley \& Bringham, 2009). In Nakuru County, studies on the determinants of financial sustainability of NGOs are still inadequate.

\subsection{Statement of the Problem}

The attainment of financial sustainability is a key component of a NGO. Financial sustainability allows the NGOs to provide larger and more complex services. There is no doubt that with the increasing demands on the state by the citizens, the state can no longer be the sole provider of goods and services. In order for NGOs to realize their potential contribution and to efficiently manage their activities, it is essential for them to be sustainable. In Nakuru County, there has been a massive expansion of NGOs and a substantial infusion of money combined with the desire for change has led to the financing of NGOs. Although donors are the major sources of funding or NGOs, the level of donor contributions has steadily declined. This has affected the operations of NGOs' in Nakuru County. As a result, the NGOs have been unable to achieve their objectives. Also complaints concerning sustainability of NGOs have been raised by the government, the community and the donors. Preliminary studies show that NGOs have not been sustainable due to financial factors. The researcher therefore set out to investigate the financial factors determining the sustainability of NGOs in Nakuru County.

\subsection{Objectives of the Study}

(i) To determine the effect of financial resource mobilization capacity of NGOs on financial sustainability of NGOs in Nakuru County.

(ii) To establish the effect of internal financial control systems on financial sustainability of NGOs in Nakuru County.

1.4 Research Hypotheses

$\mathbf{H 0}_{1:}$ There is no statistically significant effect of financial resource mobilization capacity on financial sustainability of NGOs in Nakuru County.

$\mathbf{H O}_{2}$ : There is no statistically significant effect of internal financial control systems on financial sustainability of NGOs in Nakuru County.

\subsection{Theoretical Review}

\section{Literature Review}

The study was guided by three theories namely resource based theory, the stakeholder theory and the agency theory.

\subsubsection{Resource-Based Theory}

The resource based theory was pioneered by Kay (2005). It is based on the concept of economic rent and the view that a company is a collection of capabilities. This view has a coherence and integrative role that places it well ahead of other mechanisms of strategic decision making (Kay, 2005). The resource-based view offers critical and fundamental insights into why firms with valuable and well organized resources may enjoy superior performance (Barney, 1995). The resource-based view uses a firm's internal characteristics to explain its strategy and performance. As a firm, an NGO is an organized, unique set of accumulated assets that it can use to create, produce, and/or offer its products to a market. Resources are eligible for legal protection, can operate independently of the firm's members and intervene as factors in the production process to convert input into output (Grant, 1991). Although NGOs are classified as non-profit making organizations, they still remain economic institutions in that they use society's scarce resources (land, labour and capital) to produce goods and services of value; they have operating costs, impose costs on society to the extent that they use contributions and voluntary services to provide superior value to society and need a reliable flow of revenue to finance their mission and be financially sustainable.

\subsubsection{Stakeholder Theory}

This theory maintains that the interest of the stockholders need not harm stakeholders (Freeman, 2008). It also holds that an organization can enhance the interests of its stakeholders without damaging the interest of its wider stockholders. This theory grew in response to the economic theory of the firm. Applied to NGOs, the 
management has a responsibility to provide the stakeholders with the reports on the operations of the NGOs. It also has a responsibility to justify the value of the NGOs' spending plans (Haber, 2004). This theory was considered relevant in guiding this study because stakeholders play a significant role in ensuring the financial sustainability of the NGOs (Onyango, 2002). The role of the stakeholders is to ensure that the NGOs are financially stable and all activities are directed towards realizing the goals of the NGO. The management ensures that the NGOs are operating at optimal level in order to maximize shareholders' profits and to ensure their sustainability.

\subsection{Financial Resource Mobilization Capacity of Non Government Organizations}

According to Chitere (2010) NGOs in Kenya are still unable to mobilize adequate financial resources due to inability of NGOs to elect effective leaders. Besides, some NGOs are not transparent enough in their operations hence hindering the opportunities for people's participation in identification, prioritization and implementation of projects. Many NGOs also lack administrative and other equipment through which they can use to secure funding. This includes computers for processing documents such as project proposals, correspondence and reports to enable them obtain funding in time. According to Wanyama (2009) funding and other resources usually go to those organizations that are able to produce fancy proposals and many NGOs generally lose out on this score.

\subsection{Internal Control Systems of Non Government Organizations}

Internal control systems are all systems and procedures either financial or otherwise that are put in place so as to ensure the organization processes are run in an effective and efficient manner and to safeguard the assets of the organization. These include putting up security fences, and safe custody of resources, prenumbering of receipts, policies and manuals. These are essential as they develop an environment of orderliness and guidance in operations of an organization leading to effectiveness in financial accounting (Malvern, 2002). According to Booth (2009) internal control means not only internal check or internal audit, but the whole system of control, financial and otherwise, established by the management in order to conduct the business of the company in an orderly manner, safeguard its assets and secure as far as possible accuracy and reliability of its records (Kumar, 2011). According to Booth (2009) internal control is the process designed and implemented by those charged with governance, management, and other personnel to provide reasonable assurance about the achievement of the entity's objectives with regard to reliability of financial reporting, effectiveness and efficiency of operations and compliance with applicable laws and regulations. Internal controls are designed to provide reasonable assurance that business objectives may be achieved and that undesired events would be prevented or detected and corrected (Berger, 2006).

\subsection{Conceptual Framework}

The interaction between the variables is diagrammatical presented in Figure 2.1.

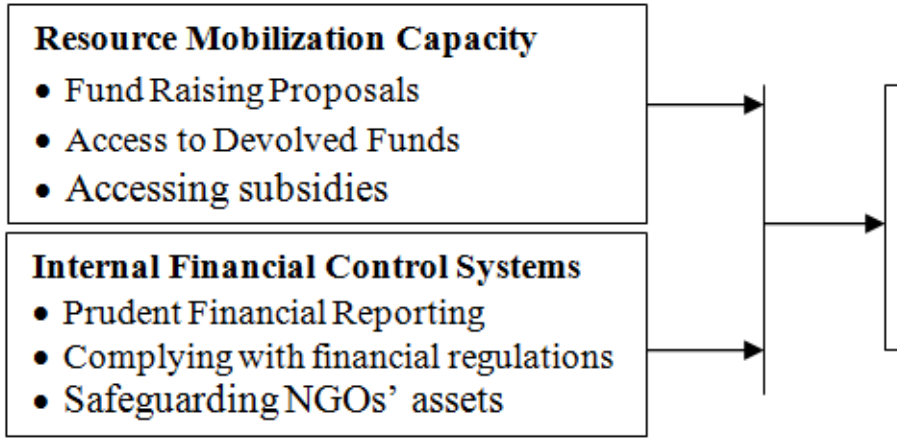

Independent Variables
Financial Sustainability of NGOs

- Project Completion Rate

- Attainment of Goals

- Accountability

\section{Dependent Variable}

\section{Figure 1: Conceptual Framework}

The conceptual framework shows the interaction between independent and dependent variables of the study. In this study the independent variables were financial resource mobilization capacity as indicated by proposal writing skills and access to devolved funds and internal financial control systems as indicated by effectiveness in financial reporting and adherence to laws and regulations. Financial sustainability of NGOs was measured by project completion, attainment of goals and accountability. 
Determinants of Financial Sustainability for Non-Governmental Organizations in Nakuru County...

\subsection{Research Gap}

The literature reviewed has revealed a general conceptualization of studies in Kenya focusing on different factors influencing financial sustainability of NGOs. However, specific studies on the financial factors determining sustainability of NGOs in Kenya, and particularly in Nakuru County have not been done. As found by Wanyama (2009), ineffective service provision, embezzlement of funds by leaders, illiteracy among members, delay in remitting and default on contributions are some of the financial factors affecting NGOs in Western Kenya. Also, there is a growing need to make use of local institutions including NGOs to implement government and community projects, hence the need to strengthen their internal financial control systems to guarantee transparency and accountability. It is in this light, therefore, that this study was undertaken to establish the determinants of financial sustainability of NGOs in Nakuru County.

\subsection{Research Design}

\section{Methodology}

The study was based on a descriptive survey design. The descriptive survey design was considered appropriate for obtaining information on the respondents' opinions about the research problem. In addition, Kerlinger (2009) points out that descriptive studies are not only restricted to fact findings but may often result in the formulation of important principles of knowledge and solutions to significant problems. The research approach was quantitative in nature and relied on primary methods of data collection.

\subsection{Target Population}

The study targeted managers, financial officers and accountants from registered NGOs in Nakuru County. The researcher used a sample of 56 NGOs. From each NGO, three officials namely program managers, grants managers and accountants were targeted. The NGOs were involved in different activities such as environmental protection, provision of water services, humanitarian assistance, health promotions, peace building initiatives, welfare and youth and children educational support.

\subsection{Sampling Design and Procedure}

The study sample was drawn from program managers, financial officers and accountants from NGOs in Nakuru County. Program managers, grants managers and accountants were involved in the study because they are knowledgeable about the operations of their NGOs, and therefore, able to provide reliable information pertaining to the study variables. Stratified random sample was used to select a study sample of 96 respondents.

\subsection{Data Collection Instruments}

Data was collected using questionnaires. The questionnaires are advantageous in that they save on time, are confidential and eliminate interviewer bias (Kombo \& Tromp, 2011). The questionnaire consisted of structured closed ended questions for ease of analysis. The questions were in the form of a Likert rating scales. The questionnaires were administered through drop and pick method.

\subsection{Data Analysis and Presentation}

Descriptive and inferential statistics were used in data analysis, with the aid of Statistical Package for Social Sciences (SPSS) version 24. Descriptive statistics included mean, standard deviations, frequencies and percentages. Regression analysis was used to establish the effect of the determinants financial sustainability of NGOs in Nakuru County at $95 \%$ level of significance. The regression model is illustrated as follows: $Y=\alpha+$ $\beta X_{1}+\beta X_{2}+\beta X_{3}+\beta X_{4}+e$

Where

$\mathrm{Y}=$ Financial Sustainability of NGOs

$\alpha=$ Constant

$\mathrm{X}_{1}=$ Financial Resource Mobilization Capacity

$\mathrm{X}_{2}=$ Internal Financial Control Systems

$\mathrm{e}=$ error

\subsection{Financial Resources Mobilization Capacity}

\section{Results and Discussion}

The researcher computed the means and standard deviation of the responses on the respondents' views regarding financial resources mobilization. The findings were as presented in table 1. 
Table 1: Respondents Perceptions on Resources Mobilization Capacity

\begin{tabular}{|l|l|l|l|l|l|}
\hline & $\mathrm{N}$ & Min & Max & Mean & Std. Dev \\
\hline There is mobilization of funds through different sources & 81 & 2 & 5 & 4.59 & .587 \\
\hline There are mechanisms for accessing and using resources & 81 & 1 & 5 & 4.30 & .813 \\
\hline There are challenges facing the NGOs in accessing funds & 81 & 1 & 5 & 3.63 & 1.134 \\
\hline There is a fundraising and development plan in my NGO & 81 & 2 & 5 & 4.04 & .858 \\
\hline $\begin{array}{l}\text { My NGO mobilizes income from sources that fit into the } \\
\text { organization's values }\end{array}$ & 81 & 2 & 5 & 4.32 & .788 \\
\hline The NGO attracts funds through good funding proposals & 81 & 1 & 5 & 4.40 & .904 \\
\hline $\begin{array}{l}\text { The NGO receive subsidies from the government and } \\
\text { donors }\end{array}$ & 81 & 1 & 5 & 3.17 & 1.263 \\
\hline Valid N (list wise) & 81 & & & & \\
\hline
\end{tabular}

From the findings, it is established that the respondents agreed that there was mobilization of funds through different sources by the NGOs $(\mathrm{M}=4.59, \mathrm{SD}=.587)$. On the other hand they agreed that there were mechanisms for accessing and using resources $(\mathrm{M}=4.30, \mathrm{SD}=.813)$, that there were challenges facing the NGOs in accessing funds $(\mathrm{M}=3.63, \mathrm{SD}=1.134)$ and that there was a fundraising and development plan in their NGOs $(\mathrm{M}=4.04, \mathrm{SD}=.858)$. Additionally, the respondents agreed that their NGOs mobilized income from different sources that fit into the organization's values $(\mathrm{M}=4.32, \mathrm{SD}=.788)$ and that the NGOs attracted funds through good funding proposals $(\mathrm{M}=4.4, \mathrm{SD}=.904)$. There was agreement in respondents' views with almost all but two statements having standard deviation values greater than one.

\subsection{Internal Financial Control}

The study also sought to establish the respondents' perceptions in regard to internal financial control. The means and standard deviations were computed for all the responses and the findings were as depicted in table 2.

Table 2: Respondents Perceptions on Internal Financial Controls

\begin{tabular}{|l|l|l|l|l|l|}
\hline & $\mathrm{N}$ & $\mathrm{Min}$ & $\mathrm{Max}$ & Mean & Std. Dev \\
\hline There is financial transparency in the operations of the NGO & 81 & 2 & 5 & 4.36 & .76 \\
\hline Financial controls used safeguards the NGOs assets and records & 81 & 2 & 5 & 4.42 & .63 \\
\hline Financial controls in my NGO lead to achievement of its financial objectives & 81 & 2 & 5 & 4.22 & .88 \\
\hline Financial reporting in my NGO is effective and efficient & 81 & 1 & 5 & 4.09 & 1.02 \\
\hline Finances are used according to financial regulations and policies in my NGO & 81 & 2 & 5 & 4.26 & .73 \\
\hline Internal control address risks that threaten success of my NGO & 81 & 1 & 5 & 4.12 & .90 \\
\hline Operations of the NGO are done according to budgetary allocations & 81 & 1 & 5 & 4.07 & 1.04 \\
\hline Valid N (list wise) & 81 & & & & \\
\hline
\end{tabular}

The results show that the respondents agreed with all the assertions regarding internal financial controls. They obliged that there is financial transparency in the operations of the NGO $(\mathrm{M}=4.36, \mathrm{SD}=.763)$, that financial controls used safeguarded the NGOs assets and records $(\mathrm{M}=4.42, \mathrm{SD}=.630)$ and that the financial controls in their NGOs lead to achievement of their financial objectives $(\mathrm{M}=4.22, \mathrm{SD}=.880)$. Respondents also agreed that financial reporting in their NGOs is effective and efficient $(\mathrm{M}=4.09, \mathrm{SD}=1.002)$ that finances are used according to financial regulations and policies in the respective NGOs $(\mathrm{M}=4.12, \mathrm{SD}=.900)$. Additionally, respondents observed that the operations of the NGO are done according to budgetary allocations $(\mathrm{M}=4.07$, $\mathrm{SD}=1.046$ ). Almost all the statements, except two, had standard deviation values less than 1 indicating greater cohesions in respondents' views.

\subsection{Financial Sustainability}

The researcher sought to establish the respondents' perceptions regarding financial sustainability of the NGOs. The findings in terms of means and standard deviations were as shown in table 3 .

Table 3: Perception on NGOs Financial Sustainability

\begin{tabular}{|l|l|l|l|l|l|}
\hline & N & Min & Max & Mean & Std. Dev \\
\hline My NGO completes its projects on time & 81 & 3 & 5 & 4.44 & .725 \\
\hline The needs of the community are met on time & 81 & 1 & 5 & 4.10 & .982 \\
\hline The NGO operates efficiently and proactively to environmental threats & 81 & 2 & 5 & 4.15 & .792 \\
\hline There is accountability in financial management in my NGO & 81 & 1 & 5 & 4.49 & .760 \\
\hline Goals and objectives of the NGO are attained on time & 81 & 2 & 5 & 4.25 & .767 \\
\hline There is certainty of survival of the NGO & 81 & 1 & 5 & 3.88 & .900 \\
\hline The NGO has a stable financial position & 81 & 1 & 5 & 3.47 & 1.141 \\
\hline Valid N (listwise) & 81 & & & & \\
\hline
\end{tabular}


The findings showed that the respondents concurred that their NGOs completes their projects on time $(\mathrm{M}=4.44, \mathrm{SD}=.725)$ that the needs of the community are met on time $(\mathrm{M}=4.10, \mathrm{SD}=.982)$ and that the NGOs operate efficiently and proactively to environmental threats $(\mathrm{M}=4.15, \mathrm{SD}=.792)$. Respondents further exuded confidence that there is accountability in financial management in their NGOs $(\mathrm{M}=4.49, \mathrm{SD}=.760)$, that goals and objectives of the NGOs are attained on time $(\mathrm{M}=4.25, \mathrm{SD}=.767)$ and that there is certainty of survival of the NGOs $(\mathrm{M}=3.88, \mathrm{SD}=.900)$. However, the respondents were undecided on whether the NGOs have a stable financial position $(\mathrm{M}=3.47, \mathrm{SD}=1.141)$. There was evidence of greater cohesion in respondents' views with all apart from aspect registering standard deviation values less than 1.

\subsection{Inferential Statistics}

The study sought to establish the underlying relationships between variables and the extent to which the independent variables influenced the dependent variables. Correlation analysis and multiple regression analysis were used to accomplish this purpose.

\subsubsection{Financial Resource Mobilization Capacity and NGOs Financial Sustainability}

The researcher established the relationship between financial resource mobilization and the financial sustainability of NGOs in Nakuru County. The composite scores for financial resource mobilization were correlated with those of financial sustainability. Pearson correlation coefficient was used to show the relationship between the two variables. The findings are presented in table 4 .

Table 4: Relationship between Financial Resources Mobilization and Financial Sustainability

\begin{tabular}{|l|l|l|l|}
\hline \multicolumn{2}{|c|}{} & \multicolumn{2}{|l|}{ Financial Resource Mobilization } \\
\hline Financial Sustainability & Pearson Correlation & .194 & \\
\cline { 2 - 5 } & Sig. (2-tailed) & .082 & \\
\cline { 2 - 5 } & $\mathrm{N}$ & 81 & \\
\hline
\end{tabular}

The findings indicated the presence of a weak positive relationship ( $r=.194, p=.082)$ between financial resources mobilization and the financial sustainability of the NGOs. However, the relationship was found to be statistically insignificant at $p<.01$ level of significance. The researcher observed that financial resource mobilization was a determinant of NGOs' financial sustainability. Therefore, the first hypothesis $\mathbf{H}_{\mathbf{0 1}}$ that stated that there was no statistically significant effect of financial resource mobilization capacity on financial sustainability of NGOs in Nakuru County was accepted.

\subsubsection{Internal Financial Control Systems and NGOs Financial Sustainability}

The second objective of the study was to establish the effect of internal financial control systems on financial sustainability of NGOs in Nakuru County. Pearson correlation coefficient was used to establish the relationship between internal financial control and financial sustainability and to test the hypothesis which stated that there was no statistically significant effect of internal financial control systems on financial sustainability of NGOs in Nakuru County. The results are presented in table 5.

Table 5: Relationship between Internal Financial Control and Financial Sustainability

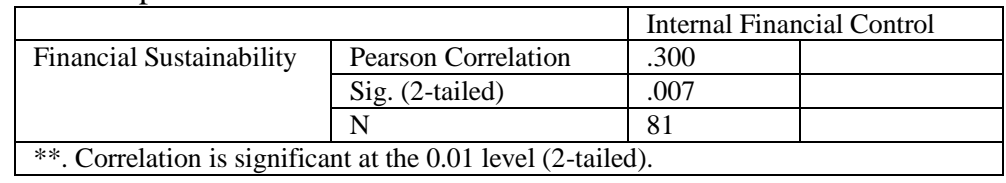

The researcher found out that there was a positive relationship $(r=.300, p=.007)$ between internal financial control systems and the NGOs financial sustainability. The relationship was statistically significant at $\mathrm{p}<.01$ level of significance. Therefore the null hypothesis $\mathbf{H}_{\mathbf{0 2}}$ which stated that there was no statistically significant effect of internal financial control systems on financial sustainability of NGOs in Nakuru County was rejected. The researcher concluded that the financial sustainability of the NGOs in Nakuru County depended to a large extent on internal financial controls systems.

\subsection{Regression Model}

The study fitted a regression model for this study to show the relationship between the independent variables and the dependent variable. Linear regression analysis was performed and the results presented in table 6. 
Table 6: Model Summary

\begin{tabular}{|l|l|l|l|l|}
\hline Model & $\mathrm{R}$ & R Square & Adjusted R Square & Std. Error of the Estimate \\
\hline 1 & $.358^{\mathrm{a}}$ & .128 & .083 & .53084 \\
\hline
\end{tabular}

The model summary indicated the presence of a weak positive multiple correlation $(\mathrm{R}=.358)$ between the independent variables and the dependent variable. Further, the R-squared value of 0.128 indicated that the independent variables accounted for $12.8 \%$ of the total variance in the financial sustainability. The researcher observed that the independent variables and the dependent variable were not mutually exclusive. The analysis of variance yielded the results presented in table 7.

Table 7: ANOVA $^{\mathrm{a}}$

\begin{tabular}{|l|l|l|l|l|l|l|}
\hline \multicolumn{2}{|l|}{ Model } & Sum of Squares & df & Mean Square & F & Sig. \\
\hline \multirow{3}{*}{1} & Regression & 3.155 & 4 & .789 & 2.799 & $.032^{\mathrm{b}}$ \\
\cline { 2 - 7 } & Residual & 21.416 & 76 & .282 & & \\
\cline { 2 - 7 } & Total & 24.571 & 80 & & & \\
\hline
\end{tabular}

The study established that the F-ration $\left(\mathrm{F}_{(4,76)}=2.799, \mathrm{p}=.032\right)$ was statistically significant at $\mathrm{p}<.05$ level of significance. This showed that the independent variables taken together significantly influenced the financial sustainability of the NGOs in Nakuru County. The model coefficients values from the regression were as presented in table 8 .

Table 8: Coefficients ${ }^{\mathrm{a}}$

\begin{tabular}{|l|l|l|l|l|l|l|}
\hline \multicolumn{2}{|l|}{ Model } & Unstandardized Coefficients & Standardized Coefficients & t & \multirow{2}{*}{ Sig. } \\
\cline { 3 - 7 } \multicolumn{2}{|c|}{1} & B & Std. Error & Beta & & \\
& (Constant) & 2.545 & .763 & & 3.337 & .001 \\
\cline { 2 - 7 } & Financial Sustainability & .048 & .145 & .041 & .332 & .741 \\
\cline { 2 - 7 } & Internal Financial Control & .289 & .111 & .297 & 2.608 & .011 \\
\hline
\end{tabular}

From the model coefficients table, the following mathematical model was fitted $\mathrm{Y}=2.545+.048 \mathrm{X}_{1}+.289 \mathrm{X}_{2}$

From the derived model, with all the other factors remaining constant, the effect of financial resources mobilization capacity is a multiple of .048 while the effects of internal financial controls is a multiple of .289.

\subsection{Conclusions}

\section{Conclusions and Recommendations}

From the findings, the researcher concluded that financial resource mobilization capacity was not statistically significant in determining the financial sustainability of the NGOs in Nakuru County. However, internal financial control systems significantly influenced the financial sustainability of NGOs in Nakuru County. Internal control system was shown to be positively correlated with financial sustainability of the NGOs.

\subsection{Recommendation of the Study}

From the study findings, it is recommended that the NGOs' policy makers should come up with elaborate internal control systems. This would enhance the monitoring of NGOs activities and financial transactions. Secondly the researcher recommended that the organization should enhance their financial resources mobilization strategies. This may enhance the financial sustainability of the organization. The findings indicated that the four variables taken together influence the financial sustainability of the organization and therefore none of the variables can be neglected.

\section{References}

[1] Ashoka, J. \& Mango, K. (2015). An Assessment of NGO's Institutional Performance; South-Western Publishing.

[2] Barney, K. (1995). Financial Planning for Not-for-profit Organizations, New York: John Wiley \& Sons, Inc.

[3] Berger, A. N. (2006). Capital structure and firm performance: a new approach to testing agency theory and an application to the banking industry, Journal of Banking and Finance, 2(3), 504-515.

[4] Besley, S. \& Brigham, E. F. (2009). Essentials of Managerial Finance. USA: South-Western Publishing Co.

[5] Booth, P. (2009). Accounting and Accountants in Voluntary Organization. New York: John Wiley \& Sons, Inc.

[6] Brinkerhoff, G., \& Goldsmith, K. (2010). Non-governmental Organizations-Performance and Accountability. Beyond the Magic Bullet, Earthscan Publications, London.

[7] Carroll, R., \& Stater, T. (2009). Understanding Sustainability of not for profit organizations: Resource Guide. New Delhi: Vikas Publishing House PVT Ltd.

[8] Chitere, P. (2010). Community Development: Its inception and Practice with Emphasis on Africa, Nairobi: Gideon S. Were Press.

DOI: $10.9790 / 487 X-1809028188 \quad$ www.iosrjournals.org $\quad 87 \mid$ Page


[9] Clark, P. (2003). Empowering Communities: A Casebook from West Sudan, Oxfam Publications.

[10] Freeman, K. (2008). A Theory of Capital Structure Adjustment Speed. Working paper, University of Florida, USA.

[11] Grant, R. M. (1991). Theory of competitive advantage: implications for strategy formulation in Non Governmental Organization, Management Review 2(5), 114-135.

[12] Kay, J. (2005). Building communities from the Inside out: A path Toward Finding and Mobilizing a Community's Assets. Evanston, IL: Institute for Policy Research.

[13] Kerlinger, F. N. (2009). Foundations of Behavioral Research, New York: Holt and Rinehart.

[14] Kombo, D. K. \& Tromp, D. L. (2011). Project and Thesis Writing: An Introduction. Pauline's Publications Africa.

[15] Kumar, R. (2011). Auditing Principles and Practice. New Delhi: PHI Learning Private Ltd.

[16] Lynn, E. (2013). The Road to Financial Sustainability: How Managers, Government, and Donors in Africa Can Create a Legacy of Viable Public and Non-Profit Organizations. Technical Paper No. 85.

[17] Malvern, G. (2002). Financial and accounting Guide for Not-for-Profit Organizations. London: Wiley and Sons.

[18] Onyango, S. (2002). NGOs do it better: An Efficiency Analysis of NGOs in Development delivery. Development Update (3) 4.

[19] Padilla, L. M, Staplefoote, K., \& Morganti, K. (2012). Financial Sustainability for Non-profit Organizations. New Delhi: Vikas Publishing House PVT Ltd.

[20] Pratt, V. \& Hailey, J. (2012). Understanding Private Donors in International Development, Briefing Paper 31, INTRAC, Oxford.

[21] Roll, P. (2009). Financial and accounting Guide for Not-for-Profit Organizations. London: Wiley and Sons.

[22] Serageldin, W. (2006). Early Warnings on Factors influencing NGOs Status, Participatory Development Centre, Nairobi.

[23] Stoner, M. (2003). Community-Based Organizations, Agencies and Groups. American Journal of Public Health, 90(6), 917-923.

[24] Tuckman, W., \& Chang, A. (2009). Sustainability: World Vision Transformational Development Indicators. New Delhi: Vikas Publishing House.

[25] Wanyama, F. (2009). Interfacing the State and the Voluntary Sector for African Development: Lessons from Kenya, International Journal of Social Science and Education, 3(4), 8-13. 